The Journal of Teaching and Learning Vol. 12, No. 2 (December 2018), pp. 70-73.

https://jtl.uwindsor.ca

Book Review:

\title{
Transforming Conversations: Feminism and Education in Canada since 1970
}

by Dawn Wallin and Janice Wallace (Eds.)

Montreal, Quebec, Canada: McGill-Queen's University Press, 2018, 281 pages

ISBN: 978-0-7735-5357-6 (paperback)

\section{Reviewed by:}

Jillian Authier, OCT

Greater Essex County District School Board

Feminism has a lengthy and complex past in Canada. The work of first and second wave feminism can be attributed to many of the gains Canadian women have made politically, socially, professionally, and economically in the last century. Today, feminism continues to evolve. In an era when the Prime Minister of Canada, Justin Trudeau, openly declares himself a feminist (Wallin \& Wallace, 2018), the term is both commonplace, and yet, still divisive. Feminism today often includes the lens of intersectionality and the ways in which race, gender, class, sexual-orientation, able-ness and ethnicity need to be considered when discussing the experiences of all women.

In the book, Transforming Conversations: Feminism and Education in Canada since 1970, Dawn Wallin and Janice Wallace co-edit a collection of essays to look at the role feminism has played, and continues to play, in Canadian education. Wallin and Wallace themselves are both well-versed in the lived experiences of feminism and academia. Wallace is professor emerita at the Faculty of Education in the University of Alberta and Janice Wallace is a professor and an associate dean in the College of Education at the University of Saskatchewan. Together, they take on the daunting task of trying to answer what they identify as their core question of the book: "What effect, if any, has feminism had on Canadian education since the Royal Commission on the Status of Women, and to what end?" (Wallin \& Wallace, 2018, p.10). Wallin and Wallace also state that their hope for this book is that it allows readers to look back on how feminism has helped shape our education system as it exists now, while prompting conversations about the ways feminism can shape future avenues in education. 
Wallin and Wallace are upfront in stating the near impossibility of addressing all areas of feminism and all feminist theories in one book. Indeed, the introduction spends a great deal of time outlining what the book is not and recognizing the potential shortcomings in not being able to include all voices from all feminist theories. They state, "we recognize that it is impossible to present a fully encompassing text on the influence of feminism in Canadian education. Rather, we view this book as an invitation to a critical conversation that continues" (Wallin \& Wallace, 2018, p. 10). Remarkably, Wallin and Wallace are able to curate a collection of essays that include perspectives from women who have been doing the work for decades at various levels of the education system. They weave these narratives into a book that is both honest and poignant about feminism's impact on Canadian education.

Transforming Conversations: Feminism and Education in Canada since 1970 is broken down into three parts. Each part contains a collection of essays from other feminist scholars and activists that speak to various ways feminism has impacted and influenced their lives and the field of education. Part One, entitled "Discourses of Teaching: Speaking Up," examines the historical impact feminism had in the classrooms and lives of feminist educators in the elementary and secondary school systems. Part Two, "Discourses of Leadership: Speaking Out," examines how feminists in academia have impacted the post-secondary academic environment through their work, values, and research. Part Three, "Disrupting Discourses: Speaking Back to Feminism," investigates postmodern, postcolonial feminism, the role of intersectional feminism to address issues faced by all women, not just white, middle-class, heterosexual women who largely benefited from first and second wave feminism. The essays that Wallace and Wallin have collected in this book represent the experiences of eight women, in addition to themselves. Included in some of the essays is the use of oral interviews, which lend voice to the experiences of additional women who have worked in education and the struggles they have faced in searching for equality while navigating patriarchal systems, including education. Several authors use autoethnographic accounts throughout their essays, which helps the reader connect to the personal and professional experiences of the author.

The essays in this book provide clear examples to demonstrate that feminism has indeed impacted education in Canada since the Royal Commission on the Status of Women, which is the guiding question of this book. For example, Rose Fine-Meyer (2018) highlights in her essay, "Pedagogical Change to Curriculum in Toronto Schools" how teachers altered and supplemented curriculum to include more feminist perspectives and women's experiences and the impact this had overtime on the curriculum. As well, in Jean Hewitt's (2018) essay, "Feminist Influence on Ontario Schools" she concludes by stating that, "The impact of feminism on practices and policies within the Ontario school system from 1960 to 1985 was substantial" (p.83). Wallin and Wallace find a balance in the essays they present to provide the reader with an understanding that despite the gains made through feminism, educational systems in Canada have also struggled to embrace these changes.

In conclusion, Wallin and Wallace are successfully able to assemble a collection of essays that provide insight into their core question about the effect that feminism has had on Canadian education since the 1970 Royal Commission on the Status of Women. Readers will come to 
understand the varying, and sometimes nuanced ways, that feminism has impacted Canadian education, while also recognizing the continued work that needs to be done. Further, the authors' invitation for readers to view this book as a stepping stone to continue the critical conversations about feminism in education is well received. In particular, readers may find themselves reflecting on how feminism has impacted and benefited their education, or how feminism has failed to include their voice and experience in education thus far.

\section{References}

Fine-Meyer, R. (2018). Pedagogical change to curriculum in Toronto schools. In D. Wallin \& J. Wallace, (Eds.), Transforming Conversations: Feminism and Education in Canada since 1970 (pp. 42-70). Montreal, QC: McGill-Queen's University Press.

Hewitt, J. (2018). Feminist influence on Ontario schools. In D. Wallin \& J. Wallace, (Eds.), Transforming Conversations: Feminism and Education in Canada since 1970 (pp. 71-90). Montreal, QC: McGillQueen's University Press.

Wallin, D., \& Wallace, J. (Eds.). (2018). Transforming conversations: Feminism and education in Canada since 1970. Montreal, QC: McGill-Queen's University Press. 